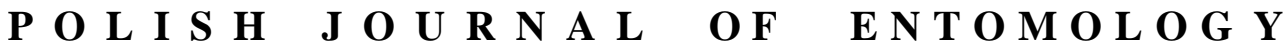

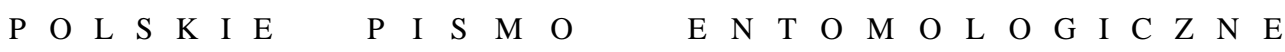

VOL. 85: 261-267

Lublin

30 June 2016

DOI: $10.1515 /$ pjen-2016-0015

\section{Rosalia longicorn Rosalia alpina (LINNAEUS, 1758) (Coleoptera: Cerambycidae) as a host of the entomopathogenic fungus Cordyceps bassiana LI, LI, HUANG \& FAN, 2001 (Ascomycota: Hypocreales)}

\author{
CZESŁAW BARTNIK $^{1}$, JAKUB MiCHALCEWICZ $^{1 *}$, RAdOSŁAW KUBIŃSKI ${ }^{2}$ \\ ${ }^{1}$ Institute of Forest Ecosystem Protection, Faculty of Forestry, University of Agriculture, \\ Al. 29 Listopada 46, 31-425 Kraków, Poland \\ ${ }^{2}$ ul. Zamkowa 63, 33-100 Tarnów, Poland
}

\begin{abstract}
The paper describes, for the first time, the occurrence of the entomopathogenic fungus Cordyceps bassiana (anamorph: Beauveria bassiana) on the imago of the endangered beetle Rosalia longicorn Rosalia alpina from the Low Beskid Mountains (the Carpathians, SE Poland). Furthermore, an isolate of the saprotrophic fungus Hypoxylon fragiforme was obtained as a result of laboratory tests on $R$. alpina specimens. Relationships between the identified fungi and $R$. alpina are discussed.
\end{abstract}

KEY WORDS: Rosalia alpina, Cordyceps bassiana, Beauveria bassiana, Hypoxylon fragiforme, endangered species, entomopathogenic fungi, saprotroph, Poland.

\section{INTRODUCTION}

The Rosalia longicorn Rosalia alpina (LINNAEUS, 1758) is an endangered and strictly protected beetle species with an Euro-Caucasian distribution (STARZYK 1992, 2004, EHNSTRÖM 2007, SHAPOVALOV 2012, IUCN 2014). In central Europe, $R$. alpina originally inhabited beech forests but was recently found to have spread into lowland beech-free forest stands (Č́̇̌žEK et al. 2009). R. alpina is a polyphagous species, although in central Europe it is mainly associated with the European beech Fagus sylvatica LiNNAEUS, 1753 (ŠVÁCHA \& DANILEVSKY 1988, BURAKOWSKI et al. 1990, SAMA 2002). The current

\footnotetext{
* Corresponding author: j.michalcewicz@ur.krakow.pl
} 
distribution of the species in Europe is highly disjunct and there are only a few isolated areas of its occurrence in central Europe (BINNER \& BUSSLER 2006). In Poland, R. alpina has withdrawn from most of its former sites and at present occurs only in certain parts of the Carpathians (MicHALCEWICZ \& CIACH 2015). The main threats to $R$. alpina are related mostly to various aspects of silviculture, which affect the presence and preservation of habitats as well as the survival of the species at different developmental stages. Natural mortality is due to different groups of predators, such as birds, lizards and ants (WITKOWSKI 2007, ADAMSKI et al. 2013).

Cordyceps bassiana LI, LI, HUANG \& FAN, 2001 is a fungus that grows naturally in the soil all over the world, parasitizes various species of arthropods and causes white muscardine disease. Beauveria bassiana BALSAMO-CRIVELLI, 1836 is an anamorph (asexual form) of the entomopathogenic fungus Cordyceps bassiana, from the phylum Ascomycota. When spores of the fungus are in contact with the host body, they germinate and penetrate the insect body through the epidermis, killing it within a few days. A white mycelium grows in the dead specimen and produces new spores. Conidia are unicellular, haploid and hydrophobic. C. bassiana growing on nutrient agar develops in the form of a white, powdery mycelium. C. bassiana parasitizes a wide range of arthropods: for this reason it is used in biological pest control (BARBARIN et al. 2012). However, the isolated strains differ in their range of hosts. Some of them, for example, are highly virulent to a small group of caterpillars, while others have a wide range of hosts (CASTRILLO et al. 2010).

\section{Acknowledgements}

We would like to thank Dominika LEDWICH MSc for her help with the genetic research in the laboratory.

\section{MATERIAL AND METHODS}

On 24 August 2015, one dead imago of $R$. alpina with a white mycelium visible on its body (Fig. 1) was found in the Magura National Park near the village of Myscowa (Low Beskid Mts., SE Poland, UTM: EV38) (leg. et coll. R. KUBIŃSKI). The imago was found among the needle litter, on the edge of a forest dominated by European silver fir Abies alba MILLER, 1759, growing on a slope between a public road and the River Wisłoka. The white mycelium was visible at different locations on the insect's body. 


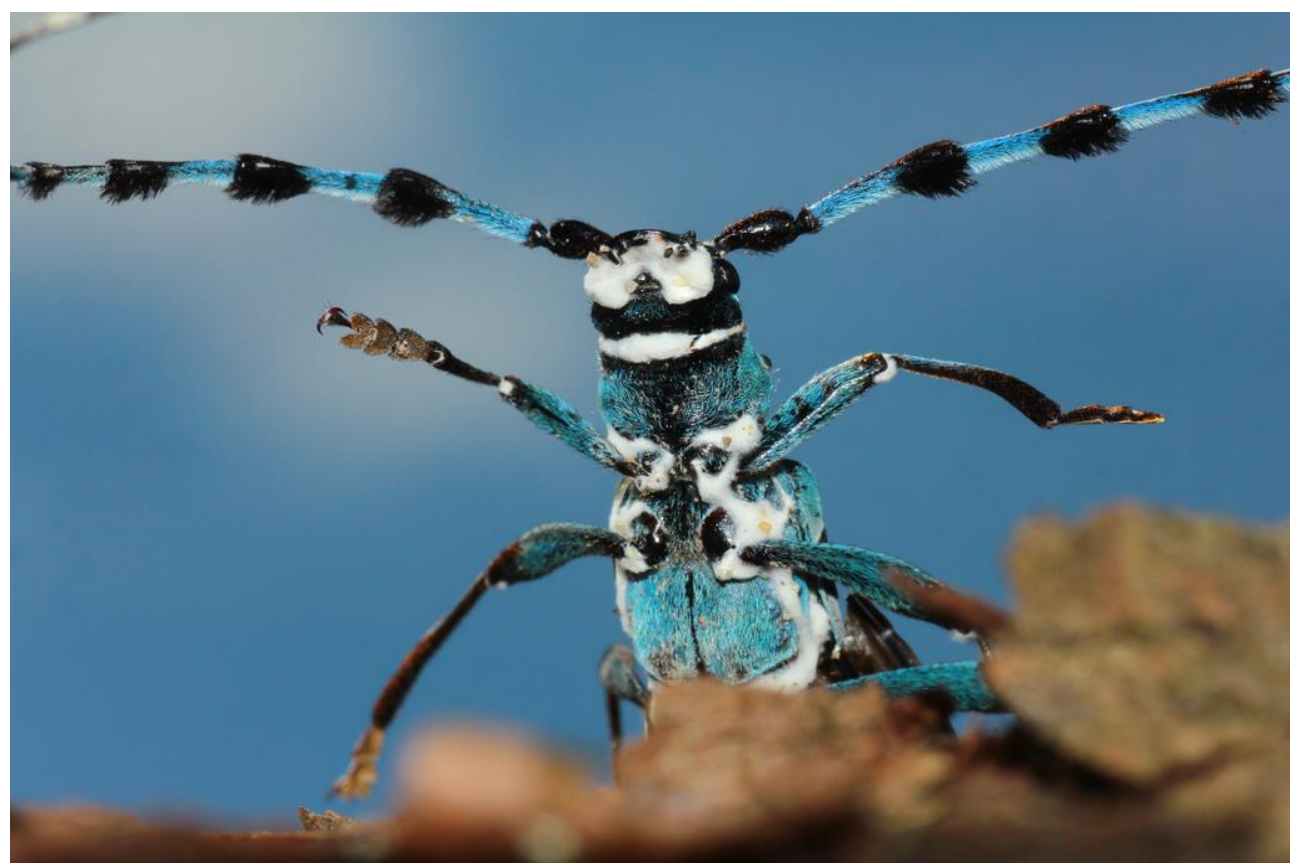

Fig. 1. Mycelium of Cordyceps bassiana visible on the underside of the Rosalia alpina imago body. Photo by R. KUBIŃSKI.

The mycelium collected from this imago of R. alpina was placed in a number of Petri dishes containing PDA medium and incubated at room temperature for 7 days in the dark. Each colony emerging from the samples was subcultured to fresh PDA medium. The isolates were identified on the basis of their morphology and the DNA sequence comparison for two gene regions (ITS). DNA was extracted using the Genomic Mini AX Plant (A\&A Biotechnology, Gdynia, Poland) using the manufacturer's protocol. The ITS rDNA region (ITS1-5.8S-ITS2) was amplified using the primers ITS 1F (GARDES \& BRUNS 1993) and ITS 4 (WhITE et al. 1990). The sequences were compared with data from GenBank using the BLAST similarity search.

\section{RESULTS AND DISCUSSION}

As a result of this laboratory study, two species of fungi - Cordyceps bassiana and Hypoxylon fragiforme (PERSOON) J. KICKX, 1835 - were isolated (Table 1). On the nutrient agar, $C$. bassiana developed in the form of a white, powdery mycelium, while $H$. fragiforme grew in the form of a light brown cottony mycelium (Fig. 2). 
Table 1. Cordyceps bassiana and Hypoxylon fragiforme isolated from the imago of Rosalia alpina (L.) (the Low Beskid Mountains, SE Poland); identification based on a comparison of ITS sequences in the GenBank database. Ls - length of the squences, Qc - query cover, E-v - E-values, Id - Identity.

\begin{tabular}{|l|c|c|c|c|c|}
\hline \multicolumn{1}{|c|}{ Fungus species } & Ls & Qc [\%] & E-v & ITS rDNA acc. no. & Id [\%] \\
\hline Cordyceps bassiana & 581 & 92 & 0.0 & AB237657.1 & 99 \\
\hline Hypoxylon fragiforme & 695 & 85 & 0.0 & EF166624.1 & 100 \\
\hline
\end{tabular}

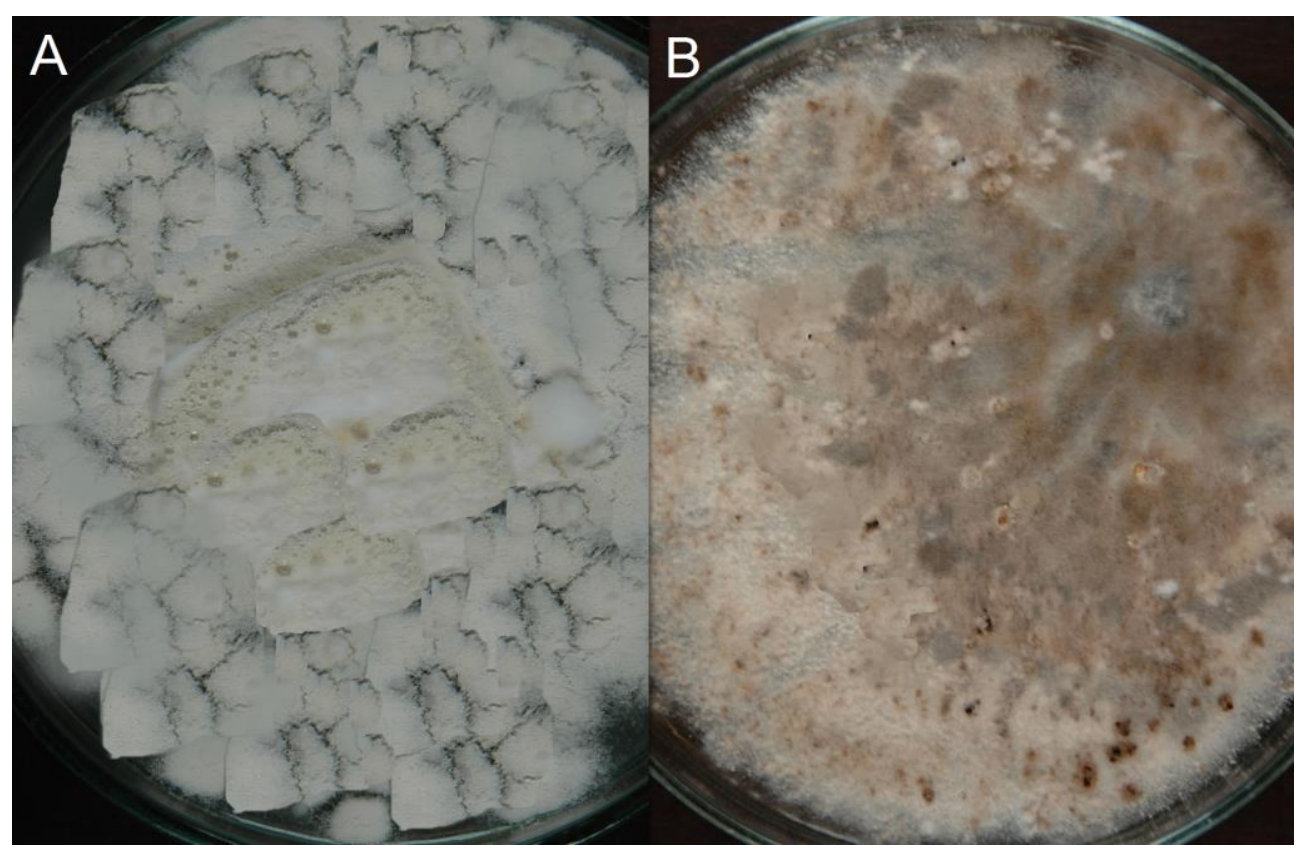

Fig. 2. Cultures of Cordyceps bassiana (A) and Hypoxylon fragiforme (B) on PDA nutrient medium. Photo by C. BARTNIK.

There are no reports in the world literature of any case of an imago of $R$. alpina being infected by $C$. bassiana. On the other hand, $C$. bassiana is known to be a pathogen of other beetle species from the family Cerambycidae and of other insects (e.g. BAŁAZY 1962, GŁOWACKA \& ŚWIEŻYŃSKA 1993, EKEN et al. 2006). A number of European studies conducted in 2000 showed, for example, that the gypsy moth Lymantria dispar (LINNAEUS, 1758), a dangerous pest of deciduous trees, is very resistant to entomopathogenic fungi. Only one strain of $C$. bassiana was found to be capable of effective infection, but solely when administered in the form of dry spores; spraying spores in a suspension was 
ineffective. Furthermore, although the fungus developed slowly (from 11 to 20 days depending on the stage of larval development), the final mortality rate was ca $80 \%$. It appears that the immunity of $L$. dispar caterpillars is caused by their natural allies - bacteria living on their body integument. It also appears that the lack of a natural lipid cover on the exoskeleton of European spruce bark beetles makes them relatively vulnerable to $C$. bassiana (WRZOSEK \& SIEROTA 2012).

The presence of $C$. bassiana on the imago of $R$. alpina is an interesting finding 1) in view of the fact that this fungus is highly pathogenic towards insects and has therefore been used in biological pest control (BARBARIN et al. 2012, CASTRILLO et al. 2010), and 2) since knowledge of the factors responsible for the limited occurrence of this endangered beetle species remains insufficient.

The second fungus, i.e. H. fragiforme (Ascomycota: Xylariales), one of the primary saprophytes of Fagus sylvatica (GUMIŃSKA \& WOJEWODA 1985), was obtained as a result of examining the $R$. alpina imago in question. This finding should probably be attributed to the common occurrence of the beetle species on $F$. sylvatica. Because of the trophic relationships of this fungus and the beetle, one can assume that $R$. alpina may be a vector carrying $H$. fragiforme. At this point, however, it is difficult to determine the modes of transmission of this fungus by $R$. alpina, especially since various transmission strategies have been found to occur in saproxylic beetles. Basically, there are two means by which such beetles transmit fungal spores: externally by mycangia, and internally through the digestive tract or reproductive organs. Different types of mycangia on the body of beetles or their mandibles can be observed in representatives of bark beetles (Curculionidae: Scolytinae). Transmission of spores through the digestive tract occurs, e.g. in the large pine weevil Hylobius abietis (LINNAEUS, 1758), which spreads annosum root rot Heterobasidion annosum (FRIES) BREFELD, 1888. This type of fungal spore transmission also occurs, for example, in representatives of the following families: longhorn beetles, sap beetles (Nitidulidae) and round fungus beetles (Leiodidae) (CROWSON 1986, GUTOWSKI 2006). In this context, further detailed research would be necessary into the possible function of $R$. alpina as a vector contributing to the spread of saprophytic fungi and into the possible role of these fungi in the death of R. alpina.

\section{REFERENCES}

Adamski P., Holly M., Michalcewicz J., Witkowski Z. 2013. Decline of Rosalia longicorn Rosalia alpina (L.) (Coleoptera: Cerambycidae) in Poland - selected mechanisms of the process. [in:] W. ZĄBECKI (ed.). The role and contribution of insects in the functioning of forest ecosystems. Wydawnictwo Uniwersytetu Rolniczego w Krakowie, Kraków, 185-200. (In Polish) 
BAŁAZY S. 1962. Observations of certain insecticidal fungi from the group of Fungi Imperfecti occurring on forest insects. Polskie Pismo Entomologiczne seria B 27-28(3-4): 149-194. (in Polish)

Barbarin A.M., Jenkins N.E., Rajotte E.G., Thomas M.B. 2012. A preliminary evaluation of the potential of Beauveria bassiana for bed bug control. Journal of Invertebrate Pathology 111(1): $82-85$.

BiNNER V., BusSLER H. 2006. Erfassung und Bewertung von Alpenbock-Vorkommen. Naturschutz und Landschaftsplanung 38(12): 378-382.

Burakowski B., MroczKowski M., StefańsKa J. 1990. Beetles - Coleoptera. Cerambycidae and Bruchidae. Catalogue of Polish Fauna XXIII, 15. Państwowe Wydawnictwo Naukowe, Warszawa. (in Polish)

CAStrillo L.A., Bauer L.S., LiU H., Griggs M.H., VAndenberg J.D. 2010. Characterization of Beauveria bassiana (Ascomycota: Hypocreales) isolates associated with Agrilus planipennis (Coleoptera: Buprestidae) populations in Michigan. Biological Control 54(2): 135-140.

Č́́žEK L., Schlaghamerský J., BoŘuckÝ J., Hauck D., HelešIC J. 2009. Range expansion of an endangered beetle: Alpine Longhorn Rosalia alpina (Coleoptera: Cerambycidae) spreads to the lowlands of Central Europe. Entomologica Fennica 20(3): 200-206.

Crowson R.A. 1986. The biology of the Coleoptera. Academic Press, London.

EHNSTRÖM B. 2007. Rosalia alpina alpbock. [In:] B. EHNSTRÖM, M. HOLMER. The Encyclopedia of the Swedish Flora and Fauna. Longhorn beetles. Coleoptera: Cerambycidae. Artdatabanken, Sveriges lantbruksuniversitet, Uppsala, 196-197.

Eken C., Tozlu G., Dane E., Coruh S., DemiRCi E. 2006. Pathogenicity of Beauveria bassiana (Deuteromycotina: Hypomycetes) to larvae of the small poplar longhorn beetle, Saperda populnea (Coleoptera: Cerambycidae). Mycopathologia 162(1): 69-71.

GARDES M., BRUNS T.D. 1993. ITS primers with enhanced specificity for basidiomycetes: application to the identification of mycorrhizae and rusts. Molecular Ecology 2(2): 113-118.

GŁowaCKa B., ŚwieżYŃSKA H. 1993. Fungi occuring on forest insects. Prace Instytutu Badawczego Leśnictwa 767: 117-136. (in Polish)

GuMiŃSKA B., WoJEwODA W. 1985. Fungi and their identification. Państwowe Wydawnictwo Rolnicze i Leśne, Warszawa. (in Polish)

GuTOwsKi J.M. 2006. Saproxylic beetles. Kosmos 55(1): 53-73. (in Polish)

IUCN (International Union for Conservation of Nature) 2014. World Conservation Monitoring Centre 1996. Rosalia alpina. [in:] The IUCN Red List of Threatened Species. Version 2014.3. Internet: http://www.iucnredlist.org. Downloaded on 18 November 2014.

Michalcewicz J., Ciach M. 2015. Current distribution of the Rosalia longicorn Rosalia alpina (LinnAeus, 1758) (Coleoptera: Cerambycidae) in Poland. Polish Journal of Entomology 84(1): 9-20.

SAmA G. 2002. Atlas of the Cerambycidae of Europe and the Mediterranean Area. Volume 1: Northern, Western, Central and Eastern Europe. British Isles and Continental Europe from France (excl. Corsica) to Scandinavia and Urals. Nakladatelství Kabourek, Zlín. 
Shapovalov A.M. 2012. Longicorn-beetles (Coleoptera, Cerambycidae) of Orenburg Region: fauna, distribution, bionomy. Archives of Orenburg Branch of Russian Entomological Society, 3. Orenburg Branch of Russian Entomological Society, Orenburg. (in Russian)

STARZYK J.R. 1992. Rosalia alpina (LinNÉ, 1758), Rosalia Longicorn. [in:] Z. GŁOWACIŃSKI (ed.). Polish Red Data Book of Animals. PWRiL, Warszawa, 295-296. (in Polish)

STARZYK J.R. 2004. Rosalia alpina (LinNAEUs, 1758), Rosalia Longicorn. [in:] Z. GŁOWACIŃski, J. NOWACKI (eds.). Polish Red Data Book of Animals. Invertebrates. Instytut Ochrony Przyrody Polskiej Akademii Nauk, Akademia Rolnicza im. A. Cieszkowskiego, Kraków - Poznań, 148-149. (in Polish)

ŠvÁcha P., DANILEvsky M.L. 1988. Cerambycoid larvae of Europe and Soviet Union (Coleoptera, Cerambycoidea). Part II. Acta Universitatis Carolinae, Seria Biologica 31(1987): 121-284.

White T.J., Bruns T., Lee S., TAYlor J. 1990. Amplification and direct sequencing of fungal ribosomal RNA genes for phylogenetics. [in:] M.A. InNIS, D.H. Gelfand, J.J. SNINSKY, T.J. WHITE (eds.). PCR protocols: a guide to methods and applications. Academic Press, San Diego, $315-322$.

Witkowski Z. 2007. A national management plan for Rosalia longicorn (Rosalia alpina L.). Ministerstwo Środowiska, Warszawa. (in Polish)

Wrzosek M., Sierota Z. 2012. Unknown fungi. Centrum Informacyjne Lasów Państwowych. Warszawa. (in Polish)

Received: 21 February 2016

Accepted: 22 March 2016 